\title{
Microbial alkyl- and aryl-sulfatases: mechanism, occurrence, screening and stereoselectivities
}

\author{
Michael Toesch • Markus Schober • Kurt Faber
}

Received: 20 September 2013 /Revised: 25 November 2013 / Accepted: 26 November 2013 /Published online: 19 December 2013

(C) The Author(s) 2013. This article is published with open access at Springerlink.com

\begin{abstract}
This review gives an overview on the occurrence of sulfatases in Prokaryota, Eukaryota and Archaea. The mechanism of enzymes acting with retention or inversion of configuration during sulfate ester hydrolysis is discussed taking two complementary examples. Methods for the discovery of novel alkyl sulfatases are described by way of sequence-based search and enzyme induction. A comprehensive list of organisms with their respective substrate scope regarding prim - and $s e c$-alkyl sulfate esters allows to assess the capabilities and limitations of various biocatalysts employed as whole cell systems or as purified enzymes with respect to their activities and enantioselectivities. Methods for immobilization and selectivity enhancement by addition of metal ions or organic (co)solvents are summarised.
\end{abstract}

Keywords Alkyl sulfatase · Inversion · Retention · Mechanism $\cdot$ Biocatalysis

\section{Introduction - inverting hydrolases}

Stereochemical changes, such as inversion of configuration involving a chiral carbon center require mechanistically sophisticated pathways (But and Toy 2007). In nature, several types of hydrolytic enzymes are able to facilitate such reactions by operating either via inversion or retention of configuration, commonly via an $\mathrm{S}_{\mathrm{N}} 2$-type mechanism (Schober and Faber 2013): haloalkane and haloacid dehalogenases (Verschueren et al. 1993), epoxide hydrolases (Kotik et al. 2012), glycosidases (Lairson and Withers 2004) and sulfatases

M. Toesch $\cdot$ M. Schober $\cdot$ K. Faber $(\bowtie)$

Department of Chemistry, Organic and Bioorganic Chemistry,

University of Graz, Heinrichstrasse 28, 8010 Graz, Austria

e-mail: kurt.faber@uni-graz.at
(Pogorevc and Faber 2002). The enzymes comprising the latter group are covered in this review with respect to their occurrence across all kingdoms of life, their substrate scope and the discovery of novel sulfatase enzymes.

Dehalogenases (EC 3.8.1.5) offer a wide variety of biotechnological applications and hence these enzymes were studied in great detail over the last decades. They are employed for the bioremediation of soils including the decontamination of chemical warfare agents (Fetzner 1998). For biocatalytic applications, they were exploited for the kinetic resolution of racemic sec-haloorganic compounds, such as haloalkanes and $\alpha$-halocarboxylic acids to obtain valuable chiral building blocks for organic synthesis (Koudelakova et al. 2013; Janssen 2007; van Leeuwen et al. 2012). The majority of haloalkane and $\alpha$-haloacid dehalogenases operate via an $\mathrm{S}_{\mathrm{N}} 2$ mechanism leading to inversion of configuration at the chiral carbon atom bearing the halide (Scheme 1). An aspartate residue within the active site acts as nucleophile, by replacing the halide to form a transient 'alkyl-enzyme intermediate'. The latter is hydrolytically cleaved by $\mathrm{H}_{2} \mathrm{O}$, which is activated by a histidine residue thereby releasing the inverted product alcohol and liberating the Asp residue, which closes the catalytic cycle (Verschueren et al. 1993).

The enzymatic ring opening of oxiranes is achieved by epoxide hydrolases (EC 3.3.2.3), which serves as detoxification strategy to yield more innocuous diols (Kotik et al. 2012). Mechanistically, hydrolysis can occur either under retention or inversion of configuration (Scheme 1). If the water molecule attacks a substituted carbon atom, the stereochemical outcome is inversion of configuration. Retention is achieved by attack at an unsubstituted carbon yielding a retained diol. From detailed studies on epoxide hydrolase from Aspergillus niger, it was shown that nucleophilic attack is caused by an aspartate residue, which forms a 'glycol-monoester enzymeintermediate'. Attack by a histidine-activated water molecule releases the diol (Widersten et al. 2010). 
Scheme 1 Stereochemical consequences of catalysis by retaining and inverting hydrolases, i.e., dehalogenases, epoxide hydrolases, glycosidases and sulfatases

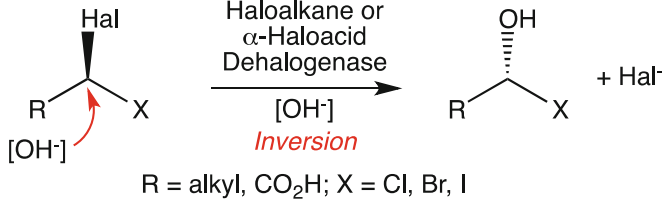<smiles>[2H][C@@H](O)CO</smiles>

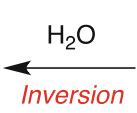

Epoxide Hydrolase

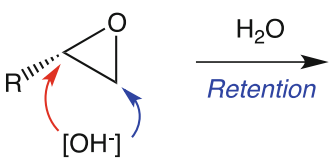<smiles>[2H][C@H](O)CO</smiles>

Glycosidase
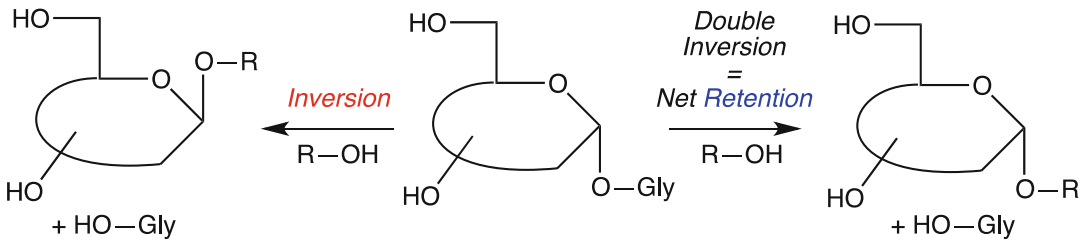

Sulfatase<smiles>[R]C([R5])O</smiles>

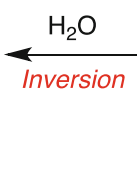

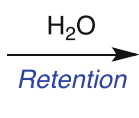

Another example for stereochemical alteration of a substrate is the enzyme class of glycosidases (EC 3.2.1.x) cleaving the glycosidic bonds. Depending on their mechanistic pathway, both inversion and retention of configuration are possible (Scheme 1). The former reaction is facilitated by a glutamate residue in the active site activating the nucleophile $(\mathrm{ROH})$, which attacks the anomeric carbon atom through an $\mathrm{S}_{\mathrm{N}}$ 2-type mechanism with inversion of configuration going in hand with release of the leaving group. Alternatively, glycoside cleavage may proceed via double inversion, leading to net retention. In this case, two glutamic acid residues are involved in catalysis. The first acts as acid via protonation of the anomeric oxygen forming a glycosyl oxonium species. In the second step, the other glutamate residue acts as base and deprotonates the nucleophile $(\mathrm{ROH})$, which in turn attacks the enzyme-bound glycosyl species and releases the retained product (O'Hagan and Schmidberger 2010; Lairson and Withers 2004).

\section{Sulfatases}

Due to the large number and broad diversity of sources, where sulfatases were obtained, they constitute a very heterogenic group of enzymes (Gadler and Faber 2007a; Hanson et al. 2004). So far, three distinct classes have been identified according to their substrate spectrum and mechanistic aspects (Kertesz 2000).

\section{Aryl sulfatases}

The name of the class is derived from the aromatic sulfate ester $p$-nitrophenyl sulfate, which is used as standard substrate for activity detection. However, many of them also act on sulfated carbohydrates, such as chondroitin sulfate and dermatan sulfate (Anson et al. 1992; Tomatsu et al. 1991). Due to their significance in humans, they have been studied in great detail with respect to their structure and mechanism and they clearly represent the best studied group of sulfatases. Fifteen of these enzymes have been identified in humans, which are linked to a lysosomal storage disease known as MSD (multiple sulfatase deficiency) (Hopwood and Ballabio 1999). Their function is to control the sulfation state of messenger molecules (Ahmed and James 1999). Several aryl sulfatases have been crystallised and structurally elucidated, including the human aryl sulfatase B (NP_000037) and the prokaryotic aryl sulfatase from $P$. aeruginosa (PA0183) (Fig. 1). The most notable aspect of aryl sulfatases is the highly conserved consensus motif C/S-X-P-X-A-X $4-T-G$ (Kertesz 2000) which applies to all of the identified enzymes within this class, except Rhodococcus ruber sulfatase (G352_02444) (Gadler and Faber 2007b). The lead residue in this motif is either a cysteine or serine, which is post- 
Fig. 1 Catalytic residues and their mode of action for the retaining sulfatase PAS from Pseudomonas aeruginosa (PDB $1 \mathrm{HDH}$, top left) and the inverting sulfatase Pisal from $P$. sp. DSM 6611 (PDB 4AXH, top right). Preferred enantiomers of the substrate 2-octyl sulfate (green) were docked into the active site using Schrödinger Maestro (Schrödinger Maestro Software Suite 2013) The flow of electrons implying nucleophilic attack is indicated by red arrows, and the $\mathrm{S}-\mathrm{O} / \mathrm{C}-\mathrm{O}$ bonds being broken are marked by scissor symbols. The schematic mechanism is given below. Some amino acid residues were omitted for clarity. Pictures were generated using Pymol (Pymol Software 2013)
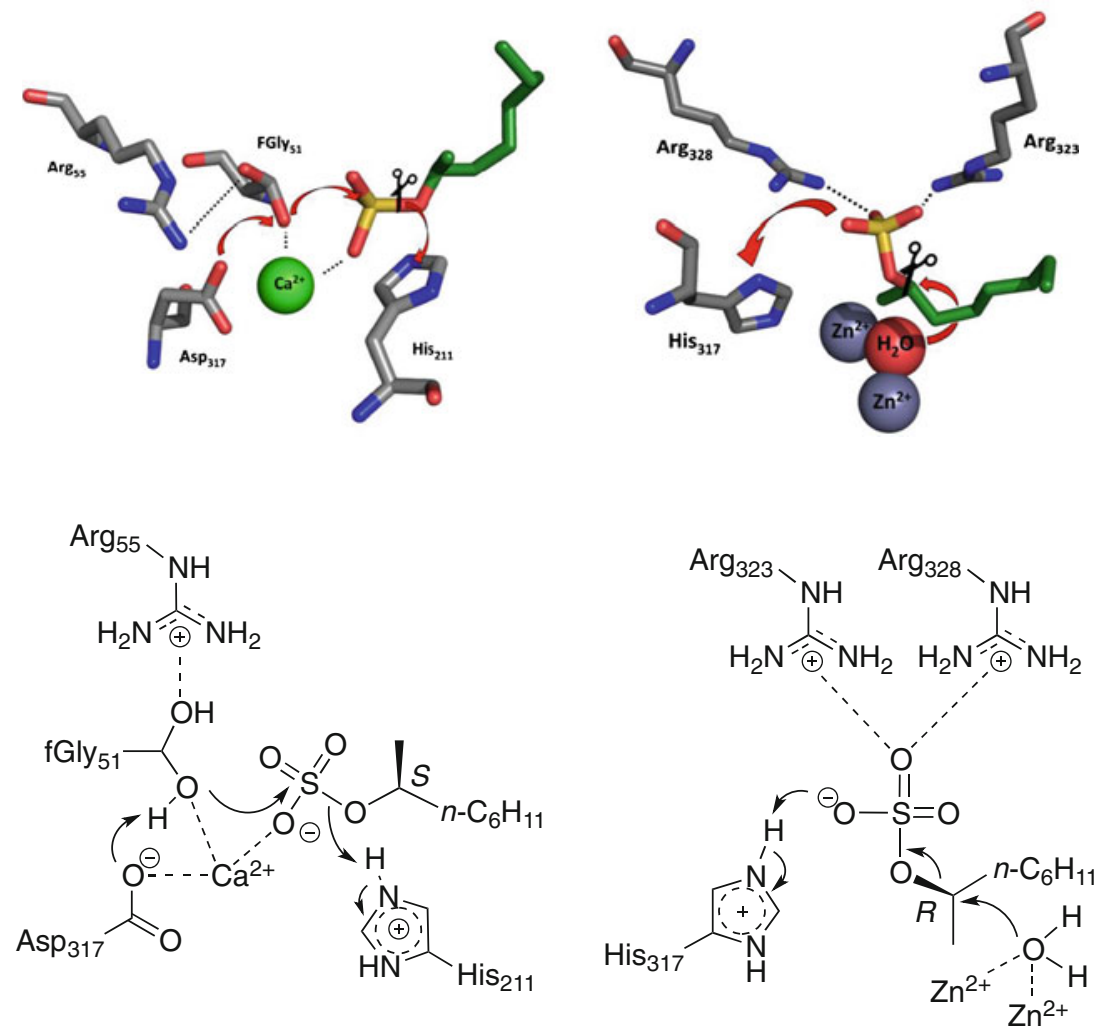

translationally modified into a catalytically active aldehyde (hydrate) known as $\mathrm{C}_{\alpha}$-formylglycine. This residue is unique to this class of enzymes and has not yet been observed in other active sites, except for phosphatases (Jonas et al. 2008). So far, cysteine is only found in eukaryotic sources, while bacterial hosts contain either a cysteine or a serine in the 'precursor' enzyme (Benjdia et al. 2010). Depending on the catalytic residue, cysteine-type sulfatases are typically found in the cytosol, whereas serine-type sulfatases are located in the periplasm (Cloves et al. 1977; Marquordt et al. 2003; Murooka et al. 1990). Due to the non-chiral nature of aryl sulfates, the stereochemical consequences of aryl sulfatase catalysis were not investigated.

\section{$\mathrm{Fe}^{2+}$-dependent sulfatases}

The second class of sulfatases belong to the $\mathrm{Fe}^{2+}$-dependent dioxygenases, which catalyse an oxidative cleavage of the sulfate ester moiety to form the corresponding aldehyde and inorganic sulfate (Müller et al. 2004). In contrast to the other sulfatases, this reaction requires $\alpha$-ketoglutarate as a redoxcosubstrate. The most prominent representative of this group is the alkyl sulfatase Atsk from Pseudomonas putida (PP4 02270) (Kahnert and Kertesz 2000). For biocatalytic applications, this class of sulfatases is less valuable, since a stereocenter is destroyed during the course of the reaction.

\section{Alkyl sulfatases}

Inspired by the observation that the bacterium Pseudomonas sp. C12B (NCIB 11753) is able to grow on the common surfactant sodium dodecyl sulfate (SDS) in the 1960s (Payne et al. 1965; Williams and Payne 1964), sulfatase research turned into a hot topic due to potential applications in bioremediation. Initially, only little attention was paid to the stereochemical implications of sulfate ester hydrolysis, but investigations on sec-alkyl sulfate substrates revealed that there were two modes of operation involved in sulfate ester cleavage (Matcham et al. 1977). The retaining pathway cleaves the $\mathrm{S}-\mathrm{O}$ ester bond, releasing the product alcohol without stereochemical alteration. In contrast, the inverting mechanism involves attack of an activated water molecule on the chiral carbon atom bearing the sulfate ester, thereby breaking the $\mathrm{C}-\mathrm{O}$ bond and releasing the inverted alcohol (Fig. 1). While the retaining pathway was elucidated already in 2001 (Boltes et al. 2001), the inverting mechanism was elucidated only recently with the sec-alkyl sulfatase Pisal (FR850678) (Knaus et al. 2012). The catalytic mechanism of this $\beta$ lactamase type enzyme involves a binuclear $\mathrm{Zn}^{2+}$ cluster activating a water molecule which launches a nucleophilic attack on the chiral carbon atom. A histidine residue protonates the sulfate moiety, transforming it into a good leaving group (Knaus et al. 2012). The synthetic potential of this enzyme was demonstrated in a sulfatase-assisted total 
synthesis of the anti-leukemic agent $(R)$-Lasiodiplodin methyl ether (Fuchs et al. 2013). Further enzymes of this class include the prim-alkyl sulfatase SdsA1 (PA0740) (Hagelueken et al. 2006) and the sec-alkyl sulfatase SdsAP (HQ189533) (Long et al. 2011), both of which originate from Pseudomonas sp. and show high sequence similarity to Pisa1. To date, only limited structural information is available for $\beta$-lactamase-type alkyl sulfatases, i.e., Pisal and SdsA1.

\section{Search for sulfatase activity}

\section{Discovery of novel sulfatases}

Considering the vast amount of possible microbial sources for sulfatases, guidelines facilitating the search for novel sulfatase activities are desirable, which can be delineated from successful case stories in the literature.

The strongest indication for aryl sulfatase activity is probably the existence of sulfatase maturation enzymes, required for the post-translational modification of a cysteine or serine into the catalytically active $\mathrm{C}_{\alpha}$-formylglycine aldehyde, or the corresponding catalytically active hydrate (Fig. 1). Given the uniqueness of this residue, it constitutes a strong marker for aryl sulfatase activity (Scheme 2).

Two systems are known to promote the maturation of Cys and/or Ser into the $\mathrm{C}_{\alpha}$-formylglycine residue. The sulfatase maturation factor 1 (SUMF1) gene codes for the so called formylglycine-generating enzyme (FGE) (Dierks et al. 2003), which acts on Cys. The second system, termed anaerobic sulfatase maturating enzymes (anSME), was initially believed to be specific for serine-type sulfatases (Hanson et al. 2004). Recent studies, however, have shown that cysteine-type enzymes are also accepted via this $S$-adenosyl-L-methionine mediated pathway (Berteau et al. 2006). The genetic origin can be found within homologues of the Klebsiella pneumoniae-derived AtsA gene (AF262989_2) and has been investigated with the sulfatase from Clostridium perfringens ATCC 13124 (Q0TTH1) (Benjdia et al. 2007). However, due to limited sequence information, this approach is not always applicable.

Metabolic demand for sulfur

As an essential element for growth, sulfur uptake occurs through various pathways, depending on the organism. Usually inorganic sulfate is available and is transformed through a cascade of reactions to yield the high-energy intermediate 3'-phosphoadenosine-5'-phosphosulfate (PAPS). Ultimately, sulfur is incorporated into the essential amino acids cysteine and methionine. In case inorganic sulfate is unavailable, organisms are forced to express other sulfur metabolizing enzymes, such as alkyl sulfatases, which are able to hydrolytically cleave inorganic sulfate from organic sulfate esters. The dependence of organisms on sulfate for growth opens a window for opportunities to induce sulfatases when sulfate esters are offered as the sole sulfur source.

Another and more general approach lies in the identification of a rich and robust (in)organic sulfate metabolism as a pointer for potential sulfatase activity, following the reasoning that the activity on (in)organic sulfate might be connected to alkyl sulfate esters and hence sulfatase activity. Sulfur metabolising organisms are typically found within the kingdom of Archaea due to their evolutionary background (Huber and Stetter 1998). This approach proved to be highly successful and led to the discovery of several highly selective sulfatase activities, such as from Sulfolobus acidocaldarius DSM 639 (Wallner et al. 2005b).

The most common indicator for sulfatase activity is the ability of organisms to grow on detergent-contaminated soil or wastewater and several bacteria have been isolated from such sources (Dodgson et al. 1954; Payne et al. 1965; Williams and Payne 1964). However, it has been shown that the reverse argument, i.e., the inability to degrade SDS should exclude sulfatase activity, cannot be drawn. A broad screening of

\begin{tabular}{|c|c|c|}
\hline \multicolumn{3}{|l|}{ Eukaryota } \\
\hline Human & $(189-249)$ & HPEGPDSTILHRPDHPVLHVSWNDAVAYCTWAGKRLPTEAEWEYSCRGGLHNRLFPWGNK \\
\hline Mouse & $(187-247)$ & HPEGPDSSILHRSNHPVLHVSWNDAVAYCTWAGKRLPTEAEWEYSCRGGLQNRLFPWGNK \\
\hline Sea urchin & $(222-282)$ & HPEGPDSSISSRMDHPVTHMSWNDATAYCQWAGKRLPTEAEWENAARGGLKNRLFPWGNK \\
\hline \multicolumn{3}{|l|}{ Prokaryota } \\
\hline PJDR2 & $(149-209)$ & HPEGPDSHIEGREDHPVIHVSWNDAMAYCEWAGRRLPTEAEWEYAGRGGLAQKRYPWGDE \\
\hline $\mathrm{CM}$ & $(182-242)$ & HPTGPGSSIEGKDNHPVVQVSYEDAQAYAKWAGKRLPTEAEWEFAARGGLEQATYAWGDK \\
\hline $\mathrm{AC}$ & $(138-195)$ & HPWGLNNSKQPAPHEPVRMVTWNDAYAYANWLGHDLPTELEWEYAAKGFQQNSDIGP - - - \\
\hline RS & $(1-35)$ & - - \\
\hline
\end{tabular}

Scheme 2 Partial sequence alignment of SUMF1 gene derived proteins. PJDR2, Paenibacillus sp. JDR-2 (YP 003009726); CM, Cupriavidus metallidurans (YP_586663); AC, Acinetobacter calcoaceticus (YP 004994666); RS, putative FGE-protein from Ralstonia solanacearum RFBP2957 (YP_003747422); human (NP_877437); mouse (NP_666049); sea urchin (XP_782973). Sequence alignment was done with clustal omega (Sievers et al. 2011). Numbers in brackets indicate the aligned amino acid residues. Letters highlighted in bold display the conserved sequence across Eukaryota and Prokaryota 
bacteria and fungi by Gadler and Faber in 2007 for potential sulfatase activity on 2-octyl sulfate resulted in several highly active strains from Pseudomonas sp., together with many inactive candidates (Gadler and Faber 2007b). The most recent example is the sec-alkyl sulfatase Pisa 1 isolated from Pseudomonas sp. DSM 6611. Although this enzyme is inactive on SDS, it has a remarkably broad activity on a wide variety of prim- and sec-sulfate esters (Schober et al. 2012).

Growth conditions

Forcing an organism to express the desired sulfatase activity is usually achieved by limiting the available sulfur to organically bound sources, such as short chain alkyl sulfates or (more common) the surfactant SDS. Since uptake of the preferred sulfur source (inorganic sulfate) (Kertesz and Wietek 2001) proceeds through different metabolic pathways, in comparison to organically bound sulfate (Cook et al. 1998; Lie et al. 1998; Marzluf 1994), supplementing the growth medium with sulfate esters drives the metabolism towards the desired direction. Importantly though, the chosen growth conditions should only be selective, but not growth limiting (Kertesz 2000). Under such constraints, organisms express sulfate starvationinduced (SSI) proteins. They usually include low sulfur containing enzymes, where cysteine and methionine in nonessential positions are substituted by other amino acids. P. putida strain KT2440, for example, is able to reduce the total soluble cellular thiol content 5 -fold under sulfur limiting conditions (Scott et al. 2007).

Due to the fact that the expression of aryl sulfatases in several bacteria is strongly upregulated when sulfate is unavailable (Dodgson et al. 1982; Kertesz et al. 1993), it has been suggested that sulfatase enzymes are expressed at a lower level than other proteins (Kertesz 2000), which makes selective growth constraints all the more important to successfully obtain sulfate ester hydrolysing cells. Consequently, when the growth medium of $P$. aeruginosa IFO 3901 was supplemented with intermediates of the primary sulfur assimilation pathway, such as sufate, sulfite or cysteine, no enzyme expression was observed (Harada 1964). Conversely, supplementing the growth medium of Coryneform sp. B1a with phenyl sulfate allowed the organism to accept several primary alkyl sulfates as substrates (Matts et al. 1994).

It is noteworthy that some alkyl sulfatases are only expressed at certain stages of growth or in presence of different sulfur sources, which may complicate the screening and might lead to 'false negatives' in search for sulfatases.

Prime examples for this case are the Pseudomonas strains C12B (NCIB 11753) and AE-A. The C12B strain is probably the most thoroughly examined organism regarding sulfatase activity and harbours alkyl sulfatases P1 and P2. While P1 is constitutive and expressed onwards from the late exponential phase, the P2 enzyme is inducible and expressed only transiently during the exponential phase (Cloves et al. 1977, 1980; Ellis et al. 2002). A zymographic analysis of Pseudomonas strain AE-A showed up to three different alkyl sulfatases, depending on the nature of the supplemented sulfur source. In nutrient broth, only one sulfatase could be identified. With addition of SDS to the medium, a second alkyl sulfatase was observed, which migrated further towards the anode than the first enzyme. Finally, with the branched 2butyl-1-octyl sulfate as supplement, a third alkyl sulfatase could be identified.

\section{Occurrence of microbial alkyl sulfatases}

Several higher eukaryotes have been shown to harbour sulfatases, a few have even been put to use in technical applications, such as soil sulfate analysis using a sulfatase from Helix pomatia (AF109924) (Burgundy edible snail) (Whalen and Warman 1996). Others, like human sulfatases, are connected to the lysosomal storage disorder and are an important subject of biomedical studies (Hanson et al. 2004). These enzymes, however, originate from higher eukaryotic sources, which are usually not applicable to biotransformations. Besides the difficulties in obtaining substantial amounts of biomass in a reproducible way, post-translational modification, such as glycosylation or acetylation are additional but unavoidable challenges in the expression of active proteins. In contrast, prokaryotes, lower eukaryotes and several Archaea species are advantageous in terms of fast growth rates, facile enzyme cloning and heterologous expression and usually omit the need for cellular post-translational enzyme modification, which speeds up the screening for sulfatase-harbouring organisms. The following section gives an overview of microorganisms with proven sulfatase activities together with the respective substrate scope (Table 1).

\section{Whole cell preparations}

Whole cell preparations enable fast screening procedures and less work-up compared to the use of purified enzymes, which has to be paid for by reduced average activities. A comprehensive overview of microbial strains harbouring sulfatase activities is given in Table 2 .

\section{Prokaryotic strains}

Prokaryotes encompass the largest group among all potential sulfatase harbouring organisms. In addition to their abundance, they can be easily accessed under simple growth conditions. Several strains possessing the ability to degrade sulfate-based detergents have recently been identified, which indicates the existence of sulfatases. The enantioselectivities - expressed as 'enantiomeric ratio' (E) (Straathof and Jongejan 1997) - 
Table 1 Classification of sulfate esters employed as test substrates for the screening of whole microbial cells and/or purified enzymes for sulfatase activity

\begin{tabular}{|c|c|c|c|c|c|c|c|c|c|c|}
\hline & \multicolumn{2}{|l|}{ A } & \multicolumn{2}{|r|}{ Substrate } & \multicolumn{2}{|l|}{ Type } & \multicolumn{2}{|l|}{$\mathrm{D}$} & \multicolumn{2}{|l|}{$\mathrm{E}$} \\
\hline & $R^{1}$ & $R^{2}$ & $R^{1}$ & $R^{2}$ & $R^{1}$ & $R^{2}$ & $R^{1}$ & $R^{2}$ & $R^{1}$ & $R^{2}$ \\
\hline 1 & $\mathrm{H}$ & $n-\mathrm{C}_{3} \mathrm{H}_{7}$ & $\mathrm{CH}_{3}$ & $n-\mathrm{C}_{3} \mathrm{H}_{7}$ & $\mathrm{CH}=\mathrm{CH}_{2}$ & $n-\mathrm{C}_{4} \mathrm{H}_{9}$ & $\mathrm{CH}_{3}$ & $\mathrm{C} \equiv \mathrm{C}-\mathrm{C}_{2} \mathrm{H}_{5}$ & $\mathrm{CH}_{3}$ & $3,5-\left(\mathrm{CF}_{3}\right)_{2} \mathrm{C}_{6} \mathrm{H}_{3}$ \\
\hline 2 & $\mathrm{H}$ & $n-\mathrm{C}_{4} \mathrm{H}_{9}$ & $\mathrm{CH}_{3}$ & $n-\mathrm{C}_{4} \mathrm{H}_{9}$ & $\mathrm{CH}=\mathrm{CH}_{2}$ & $n-\mathrm{C}_{5} \mathrm{H}_{11}$ & $\mathrm{CH}_{3}$ & $\mathrm{CH}_{2}-\mathrm{C} \equiv \mathrm{C}-\mathrm{CH}_{3}$ & $\mathrm{CH}_{3}$ & $p-\mathrm{F}-\mathrm{C}_{6} \mathrm{H}_{4}-\mathrm{CH}_{2}$ \\
\hline 3 & $\mathrm{H}$ & $n-\mathrm{C}_{5} \mathrm{H}_{11}$ & $\mathrm{CH}_{3}$ & $n-\mathrm{C}_{5} \mathrm{H}_{11}$ & $\mathrm{CH}=\mathrm{CH}_{2}$ & $n-\mathrm{C}_{6} \mathrm{H}_{13}$ & $\mathrm{CH}_{3}$ & $\mathrm{C} \equiv \mathrm{C}-\mathrm{Ph}$ & $\mathrm{CH}_{3}$ & $p-\mathrm{Cl}-\mathrm{C}_{6} \mathrm{H}_{4}-\mathrm{CH}_{2}$ \\
\hline 4 & $\mathrm{H}$ & $n-\mathrm{C}_{6} \mathrm{H}_{13}$ & $\mathrm{CH}_{3}$ & $n-\mathrm{C}_{6} \mathrm{H}_{13}$ & $\mathrm{CH}=\mathrm{CH}_{2}$ & $n-\mathrm{C}_{7} \mathrm{H}_{15}$ & $\mathrm{C}_{2} \mathrm{H}_{5}$ & $\mathrm{C} \equiv \mathrm{C}-\mathrm{CH}_{3}$ & & \\
\hline 5 & $\mathrm{H}$ & $n-\mathrm{C}_{7} \mathrm{H}_{15}$ & $\mathrm{CH}_{3}$ & $n-\mathrm{C}_{7} \mathrm{H}_{15}$ & $\mathrm{CH}_{3}$ & $\left(\mathrm{CH}_{2}\right)_{2} \mathrm{CH}=\mathrm{C}\left(\mathrm{CH}_{3}\right)_{2}$ & $\mathrm{C}_{2} \mathrm{H}_{5}$ & $\mathrm{C} \equiv \mathrm{C}-\mathrm{C}_{2} \mathrm{H}_{5}$ & & \\
\hline 6 & $\mathrm{H}$ & $n-\mathrm{C}_{8} \mathrm{H}_{17}$ & $\mathrm{CH}_{3}$ & $n-\mathrm{C}_{8} \mathrm{H}_{17}$ & $\mathrm{CH}_{3}$ & $\mathrm{CH}_{2}-\mathrm{CH}=\mathrm{CH}_{2}$ & $\mathrm{C} \equiv \mathrm{CH}$ & $n-\mathrm{C}_{3} \mathrm{H}_{7}$ & & \\
\hline 7 & $\mathrm{H}$ & $n-\mathrm{C}_{9} \mathrm{H}_{19}$ & $\mathrm{CH}_{3}$ & $n-\mathrm{C}_{9} \mathrm{H}_{19}$ & $\mathrm{CH}_{3}$ & $\left(\mathrm{CH}_{2}\right)_{2} \mathrm{CH}=\mathrm{CH}_{2}$ & $\mathrm{C} \equiv \mathrm{CH}$ & $\mathrm{CH}_{2}-\mathrm{CH}\left(\mathrm{CH}_{2}\right)_{3}$ & & \\
\hline 8 & $\mathrm{H}$ & $n-\mathrm{C}_{11} \mathrm{H}_{23}$ & $\mathrm{CH}_{3}$ & $n-\mathrm{C}_{10} \mathrm{H}_{21}$ & & & $\mathrm{C} \equiv \mathrm{CH}$ & $n-\mathrm{C}_{4} \mathrm{H}_{9}$ & & \\
\hline 9 & $\mathrm{H}$ & $n-\mathrm{C}_{12} \mathrm{H}_{25}$ & $\mathrm{CH}_{3}$ & $n-\mathrm{C}_{12} \mathrm{H}_{25}$ & & & $\mathrm{C} \equiv \mathrm{CH}$ & $n-\mathrm{C}_{5} \mathrm{H}_{11}$ & & \\
\hline 10 & $\mathrm{H}$ & $n-\mathrm{C}_{13} \mathrm{H}_{27}$ & $\mathrm{C}_{2} \mathrm{H}_{5}$ & $\mathrm{C}_{2} \mathrm{H}_{5}$ & & & & & & \\
\hline 11 & $\mathrm{H}$ & $n-\mathrm{C}_{14} \mathrm{H}_{29}$ & $\mathrm{C}_{2} \mathrm{H}_{5}$ & $n-\mathrm{C}_{4} \mathrm{H}_{9}$ & & & & & & \\
\hline 12 & SLI & & $\mathrm{C}_{2} \mathrm{H}_{5}$ & $n-\mathrm{C}_{5} \mathrm{H}_{11}$ & & & & & & \\
\hline 13 & $2-\mathrm{B}$ & & $n-\mathrm{C}_{3} \mathrm{H}_{7}$ & $n-\mathrm{C}_{3} \mathrm{H}_{7}$ & & & & & & \\
\hline 14 & & & $n-\mathrm{C}_{3} \mathrm{H}_{7}$ & $n-\mathrm{C}_{4} \mathrm{H}_{9}$ & & & & & & \\
\hline 15 & & & $n-\mathrm{C}_{3} \mathrm{H}_{7}$ & $n-\mathrm{C}_{6} \mathrm{H}_{13}$ & & & & & & \\
\hline 16 & & & $n-\mathrm{C}_{4} \mathrm{H}_{9}$ & $n-\mathrm{C}_{4} \mathrm{H}_{9}$ & & & & & & \\
\hline 17 & & & $\mathrm{CH}_{3}$ & $\mathrm{c}-\mathrm{C}_{6} \mathrm{H}_{11}$ & & & & & & \\
\hline 18 & & & $\mathrm{CH}_{3}$ & $\mathrm{Ph}$ & & & & & & \\
\hline 19 & & & $\mathrm{CH}_{3}$ & $\mathrm{CH}_{2}-\mathrm{Ph}$ & & & & & & \\
\hline 20 & & & $\mathrm{CH}_{3}$ & $\left(\mathrm{CH}_{2}\right)_{2}-\mathrm{Ph}$ & & & & & & \\
\hline
\end{tabular}

SLES sodium lauryl ether sulfate $\left(\mathrm{Na}^{+}{ }_{n}-\mathrm{C}_{12} \mathrm{H}_{25}-\mathrm{O}-\left(\mathrm{CH}_{2}\right)_{2}-\mathrm{O}_{-}-\mathrm{SO}_{3}{ }^{-}\right), 2-B O S$ 2-butyl-1-octyl sulfate

range from virtually nil $(E \sim 1)$ to perfect $(E>200)$ depending on the strains.

The largest phylum is occupied by proteobactera. In particular, Pseudomonas strains have been positively identified for their alkyl sulfatase activity. Newly discovered strains include Citrobacter braakii and a previously unknown Pseudomonas strain MTC 10311. Even a combination of strains - Acinetobacter calcoaecticus and Pantoea agglomerans — was successfully employed. C. braakii (strain CTM 50600) is able to degrade sodium lauryl ether sulfate over the course of $6 \mathrm{~h}$ starting from a concentration of $0.6 \mathrm{~g} \mathrm{l}^{-1}$ and the bacterium also exhibited growth up to an $\mathrm{OD}_{600}$ of 1.0 with SDS as a sole carbon source (Dhouib et al. 2003). These properties indicate the occurrence of sulfatases which enable the cells to use also the carbon moiety of the detergent for growth. A BLAST search with the (limited) available sequence information from $C$. braakii strain CTM 50600 on the basis of the protein sequences of the sulfatases from $P$. aeruginosa and Pisal did not reveal any positive hits.

The aforementioned Pseudomonas species have shown to harbour sulfatases which were thoroughly characterised and which exhibited a broad applicability for biocatalytic processes (Gadler and Faber 2007a,b; Schober et al. 2012). Another promising candidate is the strain P. aeruginosa MTC 10311. This bacterium was recently isolated from detergent contaminated soil and could degrade $1.4 \mathrm{~g}$ of SDS within $48 \mathrm{~h}$. It also showed activity at $40{ }^{\circ} \mathrm{C}$ with a depletion capacity of $90 \%$ compared to the initial amount of surfactant at this temperature (Ambily and Jisha 2012).

Interestingly, some strains only show degrading properties when they are embedded within a consortium of other bacteria, such as Acinetobacter calcoaceticus and Pantoea agglomerans. Neither A. calcoaceticus nor P. agglomerans alone was able to degrade SDS, whereas the combination of both bacteria resulted in $60 \%$ degradation within $50 \mathrm{~h}$ and complete degradation within 130 h (Abboud et al. 2007).

Eukaryotic strains

In comparison to prokaryotic sources for sulfatases, activities in eukaryotes are more scarce. Lower eukaryotic organisms, such as the green algae Volvox carteri is a potential hosts for 
Table 2 Substrate scope, activities and enantioselectivities for sulfatase-activities of whole cell preparations

\begin{tabular}{|c|c|c|c|c|}
\hline Organism & Substrate type & Conversion $(\%)^{\mathrm{a}}$ & $E^{\mathrm{b}}$ & Refs. \\
\hline \multicolumn{5}{|l|}{ Prokaryota } \\
\hline \multicolumn{5}{|l|}{ Proteobacteria } \\
\hline \multirow[t]{2}{*}{ Pseudomonas sp. C12B (NCIMB 11753) } & $\begin{array}{l}\text { A } 4,5,6,8,9,10,11,12 \\
\text { B } 3,4,5,12,14\end{array}$ & $\begin{array}{l}\text { n.d. } \\
<5-10\end{array}$ & $\begin{array}{l}\text { n.a. } \\
4-13\end{array}$ & \multirow{2}{*}{$\begin{array}{l}\text { (Gadler and Faber 2007b; } \\
\text { Thomas and White 1991 } \\
\text { Dodgson et al. 1982) }\end{array}$} \\
\hline & C 5 & $5-10$ & 1 & \\
\hline Pseudomonas sp. DSM 6978 & B $3,4,5,12,14$ & $<5-10$ & $4->200$ & (Gadler and Faber 2007b) \\
\hline Pseudomonas sp. DSM 6611 & B $3,4,5,9,14,18,20$ C 5 & $5-21$ & $6->200$ & (Gadler and Faber 2007b) \\
\hline Pseudomonas sp. S7 & A 9 & n.d. & n.a. & (Yeldho et al. 2011) \\
\hline Pseudomonas sp. AE-A & A 9 & n.d. & n.a. & (Ellis et al. 2002) \\
\hline Pseudomonas sp. AE-D & A 13 & n.d. & n.a. & (Ellis et al. 2002) \\
\hline Pseudomonas ATCC 19151 & A 9 & n.d. & n.a. & (Jovcic et al. 2010) \\
\hline Klebsiella oxytoca & A 9 & n.d. & n.a. & (Shukor et al. 2009) \\
\hline Comamonas sp. DSM 115091 & B 4 & $5-10$ & 16 & (Gadler and Faber 2007b) \\
\hline Citrobacter braakii & A 9,12 & n.d. & n.a. & (Dhouib et al. 2003) \\
\hline Rhizobiaceae sp. FCC 175 & B 4 & $>10$ & 2 & (Gadler and Faber 2007b) \\
\hline Cupriavidus necator DSM 5536 & B 4 & $<5$ & 4 & (Gadler and Faber 2007b) \\
\hline Paracoccus sp. DSM 6392 & $\begin{array}{l}\text { B } 3,4,12,14 \\
\text { C } 5\end{array}$ & $\begin{array}{l}<5-10 \\
5-10\end{array}$ & $\begin{array}{l}1-3 \\
2->200^{d}\end{array}$ & (Gadler et al. 2009) \\
\hline Ralstonia eutropha SPT0002 FCC120 & B 4 & $>10$ & 1 & (Gadler and Faber 2007b) \\
\hline Ralstonia eutropha sp. DSM 6428 & B 4 & $5-10$ & 21 & (Gadler and Faber 2007b) \\
\hline Xanothbacter autotrophicus DSM 431 & B 4 & $>10$ & 2 & (Gadler and Faber 2007b) \\
\hline Xanothbacter autotrophicus DSM 6696 & B 4 & $<5$ & 2 & (Gadler and Faber 2007b) \\
\hline Xanothbacter flavus DSM 338 & B 4 & $<5$ & 2 & (Gadler and Faber 2007b) \\
\hline Xanothbacter flavus autotrophicus DSM 3874 & B 4 & $<5$ & 7 & (Gadler and Faber 2007b) \\
\hline Achromobacter sp. FCC 175 & B 4 & $<5$ & 2 & (Gadler and Faber 2007b) \\
\hline \multicolumn{5}{|l|}{ Actinobacteria } \\
\hline \multirow[t]{2}{*}{ Rhodococcus ruber DSM $44541^{\mathrm{e}}$} & A 5,8 & $<5$ & n.a. & (Gadler and Faber 2007a) \\
\hline & В $3,4,5,6,7,12,14,15,19$ C 2 & $4-68$ & $1-21$ & (Pogorevc and Faber 2002) \\
\hline Gulosibacter molinativorax DSM 13485 & B 4 & $>10$ & 5 & (Gadler and Faber 2007b) \\
\hline Nocardia nova DSM 43843 & B 4 & $>10$ & & (Gadler and Faber 2007b) \\
\hline \multicolumn{5}{|l|}{ Planctomycetes } \\
\hline Rhodopirellula baltica DSM 10527 & $\begin{array}{l}\text { A } 5 \\
\text { B } 3,4,5,12,14 \text { C } 2,5\end{array}$ & $\begin{array}{l}26 \\
<5-18\end{array}$ & $\begin{array}{l}\text { n.a. } \\
2->200\end{array}$ & (Wallner et al. 2005a) \\
\hline \multicolumn{5}{|l|}{ Cyanobacteria } \\
\hline Synechococcus sp. PCC 7942 & $\begin{array}{l}\text { B } 3,4,5,12,14 \\
\text { C } 5\end{array}$ & $\begin{array}{l}<5-24 \\
5-10\end{array}$ & $\begin{array}{l}1-3 \\
4->200^{d}\end{array}$ & (Gadler et al. 2009) \\
\hline Synechococcus sp. RCC 556 & B $3,4,5,12,14$ & $<5-10$ & n.d./1 & (Gadler et al. 2009) \\
\hline \multicolumn{5}{|l|}{ Firmicutes } \\
\hline Bacillus cereus & A 9 & n.d. & n.a. & (Singh et al. 1998) \\
\hline Bacillus sphaericus FCC 098 & B 4 & $<5$ & 1 & (Gadler and Faber 2007b) \\
\hline \multicolumn{5}{|l|}{ Strain combination } \\
\hline Acinetobacter calcoaceticus + Pantoea agglomerans & A 9 & n.d. & n.a. & (Abboud et al. 2007) \\
\hline \multicolumn{5}{|l|}{ Archaea } \\
\hline \multicolumn{5}{|l|}{ Crenarchaeota } \\
\hline \multirow[t]{2}{*}{ Sulfolobus acidocaldarius DSM 639} & $\begin{array}{l}\text { B } 3,4,5,12,14,19 \\
\text { C } 5\end{array}$ & $\begin{array}{l}10-43 \\
5-10\end{array}$ & $\begin{array}{l}5->200 \\
\text { n.d. }\end{array}$ & \multirow[t]{2}{*}{$\begin{array}{l}\text { (Gadler and Faber 2007a; } \\
\text { Wallner et al. 2004) }\end{array}$} \\
\hline & E 2,3 & $5-10$ & 2 & \\
\hline Sulfolobus solfataricus DSM 1617 & B 4,19 & $20-56$ & $2-35$ & (Wallner et al. 2005b) \\
\hline Sulfolobus shibatae DSM 5389 & B 4,19 & $20-43$ & $2-48$ & (Wallner et al. 2005b) \\
\hline Sulfolobus metallicus DSM 6482 & B 4 & $5-10$ & 1 & (Wallner et al. 2005b) \\
\hline
\end{tabular}


Table 2 (continued)

\begin{tabular}{lllll}
\hline Organism & Substrate type & Conversion (\%) ${ }^{\mathrm{a}}$ & $E^{\mathrm{b}}$ & Refs. \\
\hline Sulfolobus hakoniensis DSM 7519 & B 4 & $5-10$ & 1 & (Wallner et al. 2005b) \\
Acidianus brierley DSM 1651 & B 4 & $5-10$ & 1 & (Wallner et al. 2005b) \\
Acidianus infernus DSM 3191 & B 4 & 25 & 1 & (Wallner et al. 2005b) \\
Acidianus ambivalens DSM 3772 & B 4 & 13 & 1 & (Wallner et al. 2005b) \\
Metallosphaera sedula DSM 5348 & B 4 & $5-10$ & 1 & (Wallner et al. 2005b) \\
Sulfurisphaera ohwakuensis DSM 12421 & B 4 & 11 & 1 & (Wallner et al. 2005b) \\
\hline
\end{tabular}

n.a. not applicable, $n . d$. not determined

${ }^{a}$ In kinetic resolutions showing high enantioselectivity, the maximum conversion is $50 \%$

${ }^{\mathrm{b}}$ Enantioselectivity is expressed as the ratio of the reaction rate of enantiomers ('enantiomeric ratio', E) (Straathof and Jongejan 1997)

${ }^{\mathrm{c}}$ Unpublished results

${ }^{\mathrm{d}}$ Improved $E$ values in presence of organic cosolvents

${ }^{\mathrm{e}}$ Crude enzyme preparation

alkyl sulfatase activity (Hallmann and Sumper 1994; Selmer et al. 1996). Higher eukaryotes, such as the Burgundy edible snail Helix pomatia contains sulfatases, whose genes have been identified and cloned (Wittstock et al. 2000), and which were found to be active on aryl sulfates (Whalen and Warman 1996; Yegles et al. 1997). Hence, they were also tested with several alkyl sulfates to investigate latent activity towards this substrate class. Moderate activity was obtained towards prim-alkyl sulfates but unfortunately no conversion was observed when sec-alkyl sulfatases were employed (Schober 2013).

A sulfatase from $V$. carteri f. nagariensis (strain HK10) could be purified to homogeneity and was assayed with aryl sulfates, such as $p$-nitrophenyl sulfate, 4-nitrocatechol sulfate and 5-bromo-4-chloro-3-indolyl sulfate and activity was detected for all of those compounds. In contrast, the alkyl sulfate SDS was not converted (Hallmann and Sumper 1994).

\section{Sulfatases from Archaea}

Owing to the importance of sulfur metabolism during the first billion of years of life, the third domain - Archaea complement a particularly rich source of sulfatases. These hyperthermophilic organisms prefer a strongly acidic environment (pH 2-3) and temperatures ranging between $55^{\circ} \mathrm{C}$ and $95{ }^{\circ} \mathrm{C}$, which is well above the usual $37^{\circ} \mathrm{C}$ (Wallner et al. $2005 \mathrm{~b}$ ). On the premise of harbouring a robust sulfur metabolism, several hyperthermophilic strains were examined in search for novel alkyl sulfatase activities by Wallner et. al. in 2005 (Wallner et al. 2005b). The occurrence of sulfatase activity was strongly influenced by the growth conditions: While cells could be obtained under availability of oxygen, no growth was observed in the absence of $\mathrm{O}_{2}$. Optimisation in terms of the carbon source revealed that sucrose was most beneficial. Among the tested species, Sulfolobus acidocaldarius DSM 639 turned out to be most promising. This strain was able to convert both linear and branched secalkyl sulfate substrates with low to good conversion and (occasionally) also excellent enantioselectivity $(E>200)$ (Wallner et al. 2004).

\section{Purified sulfatases}

Compared to the data available for whole cell preparations, only very few purified sulfatase enzymes have been characterised with respect to their substrate tolerance towards alkyl sulfates (Table 3). Since whole cells displaying low enantioselectivity most likely contain multiple sulfatases with different (or even opposite) enantiopreference, which makes protein isolation tedious and complicated, the prime target for the isolation of novel sulfatases were strains showing excellent stereoselectivites, because they are (most likely) expected to contain only a single sulfatase, which is easier to identify on the protein level.

Considering the source of purified enzymes, the majority of isolated sulfatases so far were derived from prokaryotic sources, with few exceptions, such as Helix pomatia aryl sulfatase (Thies 1979). To date, no enzyme could be purified from Archaea, despite their promising activity towards alkyl sulfates (Wallner et al. 2004, 2005b).

With Pisa1, PAS, SdsA1, Pseudomonas S1-3 (NCIB 11753 ) and SdsAP, the majority of purified sulfatases were derived from the phylum of Proteobacteria, which is not suprising, given the fact that these strains ranked among those exhibiting the highest $E$ values and activities observed in whole cell screenings. The Comamonas terrigena enzymes S1 and S2 also accepted several sec-alkyl sulfates; however, 
Table 3 Substrate scope, activities and enantioselectivities for purified sulfatases

\begin{tabular}{|c|c|c|c|c|}
\hline Kingdom & Substrate type & Conversion $^{\mathrm{a}}(\%)$ & $E^{\mathrm{b}}$ & References \\
\hline \multicolumn{5}{|l|}{ Prokaryota } \\
\hline \multirow[t]{4}{*}{ Pisal } & $\begin{array}{l}\text { A } 5 \\
\text { B } 1,2,4,6,11,12,14,18\end{array}$ & $\begin{array}{l}\text { n.d. } \\
5-57\end{array}$ & $\begin{array}{l}\text { n.a. } \\
10->200\end{array}$ & (Schober et al. 2011, 2012, 2013) \\
\hline & C $1,2,3,4,5,6,7$ & $5-50$ & $17->200^{\mathrm{c}}$ & \\
\hline & D $1,2,3,4,5,6,7,8,9$ & $5-57$ & $8->200$ & \\
\hline & E 1 & 49 & $>200$ & \\
\hline PAS & $\begin{array}{l}\text { D } 3,4,5,7,8,9 \\
\text { E } 1\end{array}$ & $\begin{array}{l}46-65 \\
30\end{array}$ & $\begin{array}{l}2->200 \\
>200\end{array}$ & (Schober et al. 2013) \\
\hline SdsA1 & $\begin{array}{l}\text { A } 3,5,7,9 \\
\text { B } 4^{\text {d }}\end{array}$ & $\begin{array}{l}\text { n.d. } \\
\text { n.d. }\end{array}$ & $\begin{array}{l}\text { n.a. } \\
\text { n.d. }\end{array}$ & (Knaus et al. 2012; Hagelueken et al. 2006) \\
\hline SdsAP & A 9 & n.d. & n.a. & (Long et al. 2011) \\
\hline Comamonas terrigena $\mathrm{CS} 1$ & B 4 & n.d. & n.d. & (Gadler and Faber 2007a) \\
\hline Comamonas terrigena $\mathrm{CS} 2$ & B $3,4,5,6,8,9$ & n.d. & n.d. & (Gadler and Faber 2007a) \\
\hline Rhodococcus ruber $\mathrm{S} 2$ & B 4 & n.d. & $21->200^{\mathrm{e}}$ & (Gadler and Faber 2007a) \\
\hline Pseudomonas S1 & B $3,4,6$ & n.d. & n.d. & (Gadler and Faber 2007a) \\
\hline Pseudomonas S2 & B 4 & n.d. & n.d. & (Gadler and Faber 2007a) \\
\hline Pseudomonas S3 & B $4,10,13,16$ & n.d. & n.d. & (Gadler and Faber 2007a) \\
\hline Coryneform sp. B1a & A $1,2,3,4,5$ & n.d. & n.a. & (Matts et al. 1994) \\
\hline Aerobacter aerogenes ${ }^{\mathrm{f}}$ & A 6 & n.d. & n.a. & (Schober 2013) \\
\hline \multicolumn{5}{|l|}{ Eukaryota } \\
\hline Helix pomatia ${ }^{\mathrm{f}}$ & $\begin{array}{l}\text { A } 6 \\
\text { D } 9\end{array}$ & $\begin{array}{l}\text { n.d. } \\
\text { n.d. }\end{array}$ & $\begin{array}{l}\text { n.a. } \\
\text { n.d. }\end{array}$ & (Schober 2013) \\
\hline
\end{tabular}

n.a. not applicable, n.d. not determined

${ }^{a}$ In kinetic resolutions showing high enantioselectivity, the maximum conversion is $50 \%$

${ }^{\mathrm{b}}$ Enantioselectivity is expressed as the ratio of the reaction rate of enantiomers ('enantiomeric ratio', $E$ ) (Straathof and Jongejan 1997 )

${ }^{\mathrm{c}}$ Improved $E$ values in presence of organic cosolvents

${ }^{\mathrm{d}}$ Only the $(R)$-enantiomer of B4 was tested

${ }^{\mathrm{e}}$ In the presence of $\mathrm{Fe}^{3+}$

${ }^{\mathrm{f}}$ Commercially available

no quantitative data are available regarding their enantioselectivity (Barrett et al. 1980). The enzyme from Coryneform sp. B1a accepted several primary alkyl sulfate esters with chain lengths ranging from three to seven carbon atoms. Aerobacter aerogenes ATCC 9621 and Helix pomatia sulfatases are commercially available and have been tested in our laboratory for their respective substrate scopes; however, they only showed a very limited substrate spectrum in comparison to other sulfatases, since they were only active on prim-sulfate esters but did not accept sec-sulfates (Schober et al. 2013).

Selectivity enhancement and immobilisation

When using whole cell systems or partially purified enzyme preparations, insufficient enantioselectivites are often encountered, which most likely are due to the existence of competing multiple sulfatases possessing different (or even opposite) stereoselectivities. In order to circumvent this drawback, several methods for the selectivity enhancement of alkyl sulfatase reactions were developed.

\section{Cosolvents}

The most convenient technique is the use of organic cosolvents, which have been applied to purified enzymes and whole cell biocatalysts alike. For the purified enzyme Pisa1 from Pseudomonas sp. DSM 6611, a thorough study for a range of common polar and apolar organic solvents was conducted. Among them, DMSO was found to suppress background hydrolysis of sulfate esters bearing activated allylic and benzylic functional groups. The latter increased $E$ values significantly. Enhanced enantioselectivities were also observed for whole cell preparations of cyanobacteria, such as Synechococcus elongatus PCC 7942 and Paracoccus 
denitrificans DSM 6392 in combination with lower alcohols, such as $\mathrm{MeOH}$, EtOH or $t$-ButOH. $E$ values could be improved up to $>200$ for both strains, albeit at the expense of decreased conversion (Gadler et al. 2009).

\section{Metal ions}

Several aryl and alkyl sulfatases depend on metal ions required for catalysis. Aryl sulfatases, for example the enzyme PAS from P. aeruginosa, relies on $\mathrm{Ca}^{2+}$ for proper orientation and binding of the negatively charged substrate (Boltes et al. 2001), whereas the alkyl sulfatase Pisa 1 from Pseudomonas sp. DSM 6611 needs two $\mathrm{Zn}^{2+}$ ions for water activation to provide a good nucleophile $\left[\mathrm{OH}^{-}\right]$for the hydrolytic cleavage. Supplementation with other metal ions, such as $\mathrm{Fe}^{2+}$ and $\mathrm{Fe}^{3+}$, were found to have a dramatic effect on the enatioselectivity of the Rhodococcus ruber DSM 44541 RS2 enzyme. In presence of $5 \mathrm{mM}$ of $\mathrm{FeCl}_{3}$, the selectivity could be improved from an E value of 3.6 to $>200$ (Pogorevc et al. 2002).

\section{Immobilisation}

Reusability and recyclability are important features of biocatalysts to make them industrially more appealing. At present, only few sulfatase preparations have been subjected to immobilisation. First successful experiments were conducted with immobilised cells of Pseudomonas C12B on polyacrylamide beads, which resulted in similar activities towards primary alkyl sulfate esters compared to the free enzyme. Total degradation of sulfate esters was observed within $48 \mathrm{~h}$ and an encouraging residual activity of $13 \%$ was retained after 13 days of use (Thomas and White 1991). Further whole cell experiments with Pseudomonas C12B and Comamonas terrigena $\mathrm{N} 3 \mathrm{H}$ were performed on various supports to evaluate their applicability as biofilms in wastewater treatment plants (Roig et al. 1998a, b). While C. terrigena N3H did not exhibit activity towards SDS, Pseudomonas $\mathrm{C} 12 \mathrm{~B}$, which is a well known SDS-degrader (Dodgson et al. 1982), was also able hydrolyse the surfactant in immobilized form (Roig et al. 1998a; Thomas and White 1990).

In 2002 Pogorevc et al. were able to bind a crude preparation of the Rhodococcus ruber DSM 44541 RS2 enzyme onto a DEAE- and Ecteola-cellulose carrier resulting in 100\% and $22 \%$ residual activity, respectively (Pogorevc et al. 2002). Further studies in this direction would certainly lead to more widespread biotechnological applications of sulfatases, given the fact that several new sulfatases have emerged since the initial immobilization studies were conducted.

Although the phylogenetic relationship of organisms harbouring alkyl sulfatases is very heterogenic, the majority of enzymes identified and characterised on a molecular level derive from prokaryotic sources. So far, a broad range of more than fifty different prim - and sec-alkyl sulfate esters tested as substrates were successfully converted to the corresponding alcohol with inversion or retention of configuration, depending on the source and nature of the enzyme. Although there are several crystal structures available, mostly of the class of aryl sulfatases, sequence and structural information are still scarce with regard to alkyl sulfatases. Given the rapid advances in molecular biology, the number of alkyl sulfatases is expected to increase significantly in the near future, which will broaden the applicability of these useful hydrolytic enzymes in the design of enantioconvergent processes for the generation of single stereoisomeric sec-alcohols from the corresponding rac-sec-sulfate esters (Schober and Faber 2013; Schober et al. 2013).

Acknowledgments Funding by the Austrian Science Fund (FWF) within the DK Molecular Enzymology (project W9) is gratefully acknowledged.

Conflict of interest The authors declare that they have no conflict of interest.

Open Access This article is distributed under the terms of the Creative Commons Attribution License which permits any use, distribution, and reproduction in any medium, provided the original author(s) and the source are credited.

\section{References}

Abboud MM, Khleifat KM, Batarseh M, Tarawneh KA, Al-Mustafa A, Al-Madadhah M (2007) Different optimization conditions required for enhancing the biodegradation of linear alkylbenzosulfonate and sodium dodecyl sulfate surfactants by novel consortium of Acinetobacter calcoaceticus and Pantoea agglomerans. Enzyme Microb Technol 41:432-439

Ahmed S, James K (1999) Derivation of a possible transition-state for the reaction catalysed by the enzyme estrone sulfatase (ES). Bioorg Med Chem Lett 9:1645-1650

Ambily PS, Jisha MS (2012) Biodegradation of anionic surfactant, sodium dodecyl sulphate by Pseudomonas aeruginosa MTCC 10311. J Environ Biol 33:717-720

Anson DS, Taylor JA, Bielicki J, Harper SG, Peters C, Gibson GJ, Hopwood JJ (1992) Correction of human mucopolysaccharidosis type-VI fibroblasts with recombinant $N$-acetylgalactosamine-4sulphatase. Biochem J 284:789-794

Barrett CH, Dodgson KS, White GF (1980) Further studies on the substrate specificity and inhibition of the stereospecific CS2 secondary alkylsulphohydrolase of Comamonas terrigena. Biochem J 191: 467-473

Benjdia A, Leprince J, Guillot A, Vaudry H, Rabot S, Berteau O (2007) Anaerobic sulfatase-maturating enzymes: radical SAM enzymes able to catalyze in vitro sulfatase post-translational modification. J Am Chem Soc 129:3462-3463

Benjdia A, Subramanian S, Leprince J, Vaudry H, Johnson MK, Berteau O (2010) Anaerobic sulfatase-maturating enzyme - a mechanistic link with glycyl radical-activating enzymes? FEBS J 277:19061920 
Berteau O, Guillot A, Benjdia A, Rabot S (2006) A new type of bacterial sulfatase reveals a novel maturation pathway in prokaryotes. J Biol Chem 281:22464-22470

Boltes I, Czapinska H, Kahnert A, von Bulow R, Dierks T, Schmidt B, von Figura K, Kertesz MA, Uson I (2001) 1.3 A Structure of arylsulfatase from Pseudomonas aeruginosa establishes the catalytic mechanism of sulfate ester cleavage in the sulfatase family. Structure 9:483-491

But TYS, Toy PH (2007) The Mitsunobu reaction: origin, mechanism, improvements, and applications. Chem Asian J 2:1340-1355

Cloves JM, Dodgson KS, Games DE, Shaw DJ, White GF (1977) The mechanism of action of primary alkylsulphohydrolase and arylsulphohydrolase from a detergent-degrading micro-organism. Biochem J 167:843-846

Cloves JM, Dodgson KS, White GF, Fitzgerald JW (1980) Specificity of P2 primary alkylsulphohydrolase induction in the detergentdegrading bacterium Pseudomonas C12B. Effects of alkanesulphonates, alkyl sulphates and other related compounds. Biochem J 185:13-21

Cook AM, Laue H, Junker F (1998) Microbial desulfonation. FEMS Microbiol Rev 22:399-419

Dhouib A, Hamad N, Hassairi I, Sayadi S (2003) Degradation of anionic surfactants by Citrobacter braakii. Process Biochem 38:1245-1250

Dierks T, Schmidt B, Borissenko LV, Peng JH, Preusser A, Mariappan M, von Figura K (2003) Multiple sulfatase deficiency is caused by mutations in the gene encoding the human $\mathrm{C}$-alpha-formylglycine generating enzyme. Cell 113:435-444

Dodgson KS, Melville TH, Spencer B, Williams K (1954) Studies on sulphatases. 8. The arylsulphatase of a strain of Alcaligenes metalcaligenes isolated from inter-tidal mud. Biochem J 58:182187

Dodgson KS, White GF, Fitzgerald JW (1982) Sulfatases of microbial origin. CRC Press, Boca Raton

Ellis AJ, Hales SG, Ur-Rehman NGA, White GF (2002) Novel alkylsulfatases required for biodegradation of the branched primary alkyl sulfate surfactant 2-butyloctyl sulfate. Appl Environ Microbiol 68:31-36

Fetzner S (1998) Bacterial dehalogenation. Appl Microbiol Biotechnol 50:633-657

Fuchs M, Toesch M, Schober M, Wuensch C, Faber K (2013) Chemoenzymatic asymmetric total synthesis of $(R)$-lasiodiplodin methyl ether through a sulfatase-based deracemization process. Eur J Org Chem 356-361

Gadler P, Faber K (2007a) New enzymes for biotransformations: microbial alkyl sulfatases displaying stereo- and enantioselectivity. Trends Biotechnol 25:83-88

Gadler P, Faber K (2007b) Highly enantioselective biohydrolysis of secalkyl sulfate esters with inversion of configuration catalysed by Pseudomonas spp. Eur J Org Chem 5527-5530

Gadler P, Reiter TC, Hoelsch K, Weuster-Botz D, Faber K (2009) Enantiocomplementary inverting sec-alkylsulfatase activity in cyano- and thio-bacteria Synechococcus and Paracoccus spp.: selectivity enhancement by medium engineering. Tetrahedron Asymmetry 20:115-118

Hagelueken G, Adams TM, Wiehlmann L, Widow U, Kolmar H, Tümmler B, Heinz DW, Schubert W-D (2006) The crystal structure of SdsA1, an alkylsulfatase from Pseudomonas aeruginosa, defines a third class of sulfatases. Proc Natl Acad Sci U S A 103: 7631-7636

Hallmann A, Sumper M (1994) An inducible arylsulfatase of Volvox carteri with properties suitable for a reporter-gene system - purification, characterization and molecular cloning. Eur J Biochem 221:143-150

Hanson SR, Best MD, Wong C-H (2004) Sulfatases: structure, mechanism, biological activity, inhibition, and synthetic utility. Angew Chem Int Ed 43:5736-5763
Harada T (1964) Formation of sulphatases by Pseudomonas aeruginosa Biochim Biophys Acta 81:193-196

Hopwood JJ, Ballabio A (1999) The metabolic and molecular bases of inherited disease, vol 3, 8th edn. McGraw-Hill, New York

Huber H, Stetter KO (1998) Hyperthermophiles and their possible potential in biotechnology. J Biotechnol 64:39-52

Janssen DB (2007) Biocatalysis by dehalogenating enzymes. In: Laskin AI, Sariaslani S, Gadd GM (eds) Adv Appl Microbiol 61:233-252

Jonas S, van Loo B, Hyvönen M, Hollfelder F (2008) A new member of the alkaline phosphatase superfamily with a formylglycine nucleophile: structural and kinetic characterisation of a phosphonate monoester hydrolase/phosphodiesterase from Rhizobium leguminosarum. J Mol Biol 384:120-136

Jovcic B, Venturi V, Davison J, Topisirovic L, Kojic M (2010) Regulation of the SdsA alkyl sulfatase of Pseudomonas sp. ATCC19151 and its involvement in degradation of anionic surfactants. J Appl Microbiol 109:1076-1083

Kahnert A, Kertesz MA (2000) Characterization of a sulfur-regulated oxygenative alkylsulfatase from Pseudomonas putida S-313. J Biol Chem 275:31661-31667

Kertesz MA (2000) Riding the sulfur cycle - metabolism of sulfonates and sulfate esters in Gram-negative bacteria. FEMS Microbiol Rev 24:135-175

Kertesz MA, Wietek C (2001) Desulfurization and desulfonation: applications of sulfur-controlled gene expression in bacteria. Appl Microbiol Biotechnol 57:460-466

Kertesz MA, Leisinger T, Cook AM (1993) Proteins induced by sulfate limitation in Escherichia coli, Pseudomonas putida, or Staphylococcus aureus. J Bacteriol 175:1187-1190

Knaus T, Schober M, Kepplinger B, Faccinelli M, Pitzer J, Faber K, Macheroux P, Wagner U (2012) Structure and mechanism of an inverting alkylsulfatase from Pseudomonas sp. DSM6611 specific for secondary alkyl sulfates. FEBS J 279:4374-4384

Kotik M, Archelas A, Wohlgemuth R (2012) Epoxide hydrolases and their application in organic synthesis. Curr Org Chem 16:451-482

Koudelakova T, Bidmanova S, Dvorak P, Pavelka A, Chaloupkova R, Prokop Z, Damborsky J (2013) Haloalkane dehalogenases: biotechnological applications. Biotechnol J 8:32-45

Lairson LL, Withers SG (2004) Mechanistic analogies amongst carbohydrate modifying enzymes. Chem Commun 2243-2248

Lie TJ, Leadbetter JR, Leadbetter ER (1998) Metabolism of sulfonic acids and other organosulfur compounds by sulfate-reducing bacteria. Geomicrobiol J 15:135-149

Long M, Ruan L, Li F, Yu Z, Xu X (2011) Heterologous expression and characterization of a recombinant thermostable alkylsulfatase (sdsAP). Extremophiles 15:293-301

Marquordt C, Fang QH, Will E, Peng JH, von Figura K, Dierks T (2003) Posttranslational modification of serine to formylglycine in bacterial sulfatases - recognition of the modification motif by the ironsulfur protein AtsB. J Biol Chem 278:2212-2218

Marzluf GA (1994) Genetics and molecular genetics of sulfur assimilation in the fungi. Adv Genet 31:187-206

Matcham GWJ, Bartholomew B, Dodgson KS, Fitzgerald JW, Payne WJ (1977) Stereospecificity and complexity of microbial sulphohydrolases involved in the biodegradation of secondary alkylsulphate detergents. FEMS Microbiol Lett 1:197-199

Matts PJ, White GF, Payne WJ (1994) Purification and characterization of the short-chain alkylsulphatase of coryneform Bla. Biochem J 304: 937-943

Müller I, Kahnert A, Pape T, Sheldrick GM, Meyer-Klaucke W, Dierks T, Kertesz M, Usón I (2004) Crystal structure of the alkylsulfatase AtsK: insights into the catalytic mechanism of the $\mathrm{Fe}(\mathrm{II}) \alpha$ ketoglutarate-dependent dioxygenase superfamily. Biochemistry 43:3075-3088

Murooka Y, Ishibashi K, Yasumoto M, Sasaki M, Sugino H, Azakami H, Yamashita M (1990) A sulfur- and tyramine-regulated Klebsiella 
aerogenes operon containing the arylsulfatase (ats $A$ ) gene and the ats $B$ gene. J Bacteriol 172:2131-2140

O'Hagan D, Schmidberger JW (2010) Enzymes that catalyse $\mathrm{S}_{\mathrm{N}} 2$ reaction mechanisms. Nat Prod Rep 27:900-918

Payne WJ, Williams JP, Mayberry WR (1965) Primary alcohol sulfatase in a Pseudomonas species. Appl Microbiol 13:698-701

Pogorevc M, Faber K (2002) Enantioselective stereoinversion of secalkyl sulfates by an alkylsulfatase from Rhodococcus ruber DSM 44541. Tetrahedron Asymmetry 13:1435-1441

Pogorevc M, Strauss UT, Riermeier T, Faber K (2002) Selectivityenhancement in enantioselective hydrolysis of sec-alkyl sulfates by an alkylsulfatase from Rhodococcus ruber DSM 44541. Tetrahedron Asymmetry 13:1443-1447

PyMOL Molecular Graphics System, Version 1.5.0.4 Schrödinger, LLC.

Roig MG, Pedraz MA, Sanchez JM (1998a) Sorption isotherms and kinetics in the primary biodegradation of anionic surfactants by immobilized bacteria: I. Pseudomonas C12B. J Mol Catal B: Enzym 4:253-270

Roig MG, Pedraz MA, Sanchez JM, Huska J, Tóth D (1998b) Sorption isotherms and kinetics in the primary biodegradation of anionic surfactants by immobilized bacteria: II. Comamonas terrigena N3H. J Mol Catal B: Enzym 4:271-281

Schober M (2013) Characterization and biocatalytic application of sulfatases. PhD thesis, Karl-Franzens University, Graz

Schober M, Faber K (2013) Inverting hydrolases and their use in enantioconvergent biotransformations. Trends Biotechnol 31:468-478

Schober M, Gadler P, Knaus T, Kayer H, Birner-Gruenberger R, Guelly C, Macheroux P, Wagner U, Faber K (2011) A stereoselective inverting sec-alkylsulfatase for the deracemization of sec-alcohols. Org Lett 13:4296-4299

Schober M, Knaus T, Toesch M, Macheroux P, Wagner U, Faber K (2012) The substrate spectrum of the inverting sec-alkylsulfatase Pisa1. Adv Synth Catal 354:1737-1742

Schober M, Toesch M, Knaus T, Strohmeier GA, van Loo B, Fuchs M, Hollfelder F, Macheroux P, Faber K (2013) One-pot deracemization of sec-alcohols: enantioconvergent enzymatic hydrolysis of alkyl sulfates using stereocomplementary sulfatases. Angew Chem Int Ed 52:3277-3279

Schrödinger Release 2013-1: Maestro, version 9.4, Schrödinger, LLC, New York, NY, 2013.

Scott C, Hilton ME, Coppin CW, Russell RJ, Oakeshott JG, Sutherland TD (2007) A global response to sulfur starvation in Pseudomonas putida and its relationship to the expression of low-sulfur-content proteins. FEMS Microbiol Lett 267:184-193

Selmer T, Hallmann A, Schmidt B, Sumper M, vonFigura K (1996) The evolutionary conservation of a novel protein modification, the conversion of cysteine to serine semialdehyde in arylsulfatase from Volvox carteri. Eur J Biochem 238:341-345

Shukor MY, Husin WS, Rahman MFA, Shamaan NA, Syed MA (2009) Isolation and characterization of an SDS-degrading Klebsiella oxytoca. J Environ Biol 30:129-134

Sievers F, Wilm A, Dineen D, Gibson TJ, Karplus K, Li W, Lopez R, McWilliam H, Remmert M, Soding J, Thompson JD, Higgins DG (2011) Fast, scalable generation of high-quality protein multiple sequence alignments using Clustal Omega. Mol Syst Biol 7:539-547
Singh K, Kumar A, Kumar A (1998) Bacillus cereus capable of degrading SDS shows growth with a variety of detergents. World J Microb Biot 14:777-779

Straathof AJJ, Jongejan JA (1997) The enantiomeric ratio: origin, determination and prediction. Enzyme Microb Technol 21:559-571

Thies W (1979) Detection and utilization of a glucosinolate sulfohydrolase in the edible snail, Helix pomatia. Naturwissenschaften 66:364-365

Thomas ORT, White GF (1990) Immobilization of the surfactantdegrading bacterium Pseudomonas C12B in polyacrylamide gel: II. Optimizing SDS-degrading activity and stability. Enzyme Microb Technol 12:969-975

Thomas ORT, White GF (1991) Immobilization of the surfactantdegrading bacterium Pseudomonas $\mathrm{C} 12 \mathrm{~B}$ in polyacrylamide gel: III. Biodegradation specificity for raw surfactants and industrial wastes. Enzyme Microb Technol 13:338-343

Tomatsu S, Fukuda S, Masue M, Sukegawa K, Fukao T, Yamagishi A, Hori T, Iwata H, Ogawa T, Nakashima Y, Hanyu Y, Hashimoto T, Titani K, Oyama R, Suzuki M, Yagi K, Hayashi Y, Orii T (1991) Morquio disease: isolation, characterization and expression of fulllength cDNA for human $N$-acetylgalactosamine-6-sulfate sulfatase. Biochem Biophys Res Commun 181:677-683

van Leeuwen JGE, Wijma HJ, Floor RJ, van der Laan J-M, Janssen DB (2012) Directed evolution strategies for enantiocomplementary haloalkane dehalogenases: from chemical waste to enantiopure building blocks. Chem Bio Chem 13:137-148

Verschueren KHG, Seljee F, Rozeboom HJ, Kalk KH, Dijkstra BW (1993) Crystallographic analysis of the catalytic mechanism of haloalkane dehalogenase. Nature 363:693-698

Wallner SR, Nestl BM, Faber K (2004) Highly enantioselective sec-alkyl sulfatase activity of Sulfolobus acidocaldarius DSM 639. Org Lett 6:5009-5010

Wallner SR, Bauer M, Würdemann C, Wecker P, Glöckner FO, Faber K (2005a) Highly enantioselective $s e c$-alkyl sulfatase activity of the marine planctomycete Rhodopirellula baltica shows retention of configuration. Angew Chem Int Ed 44:6381-6384

Wallner SR, Nestl BM, Faber K (2005b) Highly enantioselective stereoinverting sec-alkylsulfatase activity of hyperthermophilic Archaea. Org Biomol Chem 3:2652-2656

Whalen JK, Warman PR (1996) Examination of ester sulfates in Podzolic and Regosolic soils using an immobilized arylsulfatase reactor. Biol Fert Soils 23:64-69

Widersten M, Gurell A, Lindberg D (2010) Structure-function relationships of epoxide hydrolases and their potential use in biocatalysis. Biochim Biophys Acta 1800:316-326

Williams J, Payne WJ (1964) Enzymes induced in a bacterium by growth on sodium dodecyl sulfate. Appl Microbiol 12:360-362

Wittstock U, Fischer M, Svendsen I, Halkier BA (2000) Cloning and characterization of two cDNAs encoding sulfatases in the Roman snail, Helix pomatia. IUBMB Life 49:71-76

Yegles M, Mersch F, Wennig R (1997) Detection of benzodiazepines and other psychotropic drugs in human hair by GC/MS. Forensic Sci Int 84:211-218

Yeldho D, Rebello S, Jisha MS (2011) Plasmid-mediated biodegradation of the anionic surfactant sodium dodecyl sulphate by Pseudomonas aeruginosa S7. Bull Environ Contam Toxicol 86:110-113 